\title{
MEREKONSTRUKSI PEMBELAJARAN \\ PENDIDIKAN AGAMA ISLAM DAN BUDI PEKERTI DI SEKOLAH NEGERI STUDI KASUS SMA N 14 YOGYAKARTA
}

\author{
Siti Fatimah, S. Pd \\ Guru Tidak Tetap (Honorer) Mata Pelajaran Pendidikan Agama Islam, SMA N 4 \\ Yogyakarta \\ Email: sitifatimahmuslimah200395@gmail.com
}

\begin{abstract}
Great depression in 1930s and multidimensional crisis aftermath inspired some scholars to propose the idea of a new social order. Those scholars, the reconstructionist, see that it is necessary for human beings and humanity in order to survive the challenges to reconstruct their way of life: setting aside negative impacts of modernity while maintaining the good aspects. The reconstructionist see that education must play a role in building new social order by being involved in social movement and reconstruct the way of learning and teaching. In the context of learning PAI (islamic teachings educations) and morals in government schools, SMA N 4 Yogyakarta has adapted several methods relevant to the ideas of reconstructionism in education. SMA N 4 Yogyakarta has made use of cyber media as a way to develop students' understanding about materials. This school also encouraged students to be involved in community development.
\end{abstract}

Keywords: reconstructionism, islamic education, PAI.

\section{Pendahuluan}

Periode tahun 1930-an adalah dekade krisis. Depresi Besar (Great Depression) yang meluas melumpuhkan bangsa-bangsa kapitalis secara ekonomi, totalitarianisme bangkit di Eropa dan Asia, dan gejolak sosial sangat mencolok di Amerika. Bagi beberapa pengamat di Amerika, hal itu menunjukkan bahwa demokrasi itu sendiri tampaknya berada pada detik terakhir. Para pengamat ini mencatat bahwa depresi tahun 1930-an bukan lantaran kekurangan pangan atau kebutuhan pasokan material, depresi tersebut lebih tepat digambarkan sebagai kelaparan di tengah kemakmuran. Persoalan bangsa Amerika ini lebih disebabkan oleh kerancuan distribusi kekayaan dan bahan makanan daripada kelangkaan produksinya. Pada awal dekade tiga puluhan, banyak sektor bisnis lumpuh dan para politikus tampak tidak sanggup menghadapi bencana ekonomi yang meluas ini.

Dalam konteks sosial-ekonomi tersebut, George S. Counts mengembangkan sebuah 


\section{Siti Fatimah}

pendekatan yang baru terhadap pendidikan. Counts menyatakan pemikirannya dalam pidatopidato provokatifnya yang pada tahun 1932 diterbitkan dengan tajuk Dare the School Build a New Social Order? (Beranikah Sekolah Membangun Sebuah Tatanan Sosial Baru?). Pokok pikiran Counts adalah mengajak para pendidik untuk membuang mentalitas budak, agar secara hati-hati mengumpulkan kekuatan dan kemudian berjuang membentuk sebuah tatanan sosial baru yang didasarkan pada sistem ekonomi kolektif dan prinsip-prinsip politik demokratis. Ia menyeru kalangan profesional pendidikan, dari tingkat Taman Kanak-Kanak (TK) hingga Perguruan Tinggi (PT), untuk mengorganisir diri dan menggunakan kekuatan terorganisir mereka untuk kepentingan-kepentingan masyarakat luas (George R. Knight: 2007).

Kehadiran aliran rekonstruksionisme dalam pendidikan didorong adanya tuntutan yang menghendaki agar sekolah mengambil bagian dalam pembangunan masyarakat. Hal ini dikarenakan masyarakat global secara umum pada periode Great Depression mengalami ketakutan dan kebingungan dalam menghadapi perkembangan zaman.

Meski tidak menghadapi krisis ekonomi seperti pada dekade 1930an, masyarakat pada era kontemporer juga menghadapi guncangan budaya yang tak kalah hebatnya. Pada zaman ini, pola-pola kebudayaan lama banyak mengalami gangguan yang disebabkan oleh perkembangan teknologi, khususnya teknologi digital.

Fenomena ini juga turut mempengaruhi dinamika dunia pendidikan. Pada era generasi millennial ini, para siswa didik maupun pendidik banyak bersentuhan dengan gadget, baik untuk berkomunikasi, mencari informasi bahkan menghabiskan waktunya untuk mencari penyegaran (leisure) dengan memainkan games online maupun menonton live streaming. Banyak manfaat yang bisa di ambil dari gadget dan dunia maya, namun banyak juga kerugian yang didapat.

Dengan tantangan zaman yang demikian, penulis melihat perlunya penataan ulang tatanan dunia pendidikan, agar di satu sisi dapat memaksimalkan perkembangan teknologi dan di sisi yang lain dapat mencegah efek buruknya. Dalam rangka itu, rekonstruksionisme merupakan pendekatan yang relevan dalam mengembangkan pendidikan berbasis teknologi. Tanpa rekonstruksi, pendidikan akan selamanya bersifat tradisional dan tertinggal oleh zaman. Di antara ranah pendidikan yang membutuhkan rekonstruksi tatanan adalah pembelajaran Pendidikan Agama Islam dan Budi Pekerti. Bidang-bidang tersebut selama ini hanya berkutat dalam pembahasan ajaran-ajaran yang normatif dan dogmatis. Sementara masyarakat kontemporer membutuhkan tata kelola moralitas baru menghadapi tantangan era 
disrupsi.

Contoh dari tantangan yang dihadapi oleh dunia pendidikan akibat teknologi adalah banyaknya siswa sekolah menengah yang diperkenankan orangtuanya untuk mengoperasikan gadget dengan dalih untuk mempermudah komunikasi. Namun, dalam praktiknya selain digunakan untuk mempermudah komunikasi, gadget dialihfungsikan untuk hal-hal yang kurang bermanfaat dan tidak tepat guna.

Untuk itu, dalam makalah ini penulis akan menguraikan pengembangan konsep rekonstruksionisme pendidikan dan pengembangannya dalam pembelajaran Pendidikan Agama Islam dengan contoh kasus di salah satu sekolah negeri di Yogyakarta, yaitu SMA N 4 Yogyakarta.

\section{Pembahasan}

\section{Pengertian Rekonstruksionisme Pendidikan}

Kata reconstructivism berasal dari bahasa inggris reconstruct yang berarti menyusun kembali. Dalam kamus Oxford, to reconstruct bermakna to build or to form (something) again after it has been damaged or destroyed. Dalam kamus ilmiah, rekonstruksi berarti kehidupan yang merancang dan baru. Dalam konteks filsafat pendidikan, aliran reconstructivism merupakan suatu aliran yang berusaha merombak tata susunan lama dengan membangun tata kebudayaan yang menjawab tantangan zaman modern. Aliran reconstructivism pada dasarnya berangkat dari titik tolak yang sama dengan aliran perenialisme, yaitu berawal dari krisis kebudayaan modern (Jalaluddin \& Abdullah Idi: 1997). Sementara menurut Imam Barnadib, reconstructivism sebagai filsafat pendidikan menghendaki anak didik agar dibangkitkan kemampuannya untuk secara rekonstruktif menyesuaikan diri dengan tuntutan perubahan dan perkembangan masyarakat, sebagai akibat adanya pengaruh dari ilmu pengetahuan dan teknologi (Abd. Rachman Assegaf: 2014).

Aliran rekonstruksionisme adalah suatu aliran yang berusaha merombak tata susunan lama dan membangun tata hidup kebudayaan yang menjawab permasalahan-permasalahan dunia modern. Aliran rekonstruksionisme, pada prinsipnya, sepaham dengan aliran perenialisme, yaitu hendak melampaui krisis kebudayaan modern. Kedua aliran tersebut, aliran rekonstruksionisme dan perenialisme, memandang bahwa zaman modern merupakan zaman yang tatanan sosialnya terganggu oleh kehancuran, kebingungan dan kesimpangsiuran.

Walaupun demikian, prinsip yang dimiliki oleh aliran rekonstruksionisme tidaklah sama dengan prinsip yang dipegang oleh aliran perenialisme. Keduanya mempunyai visi dan cara yang berbeda dalam pemecahan yang akan ditempuh untuk mengembalikan kebudayaan 


\section{Siti Fatimah}

yang serasi dalam kehidupan. Aliran perennialisme memilih cara tersendiri, yakni dengan kembali ke alam kebudayaan lama atau dikenal dengan regressive road culture yang mereka anggap paling ideal (Muhammad Kristiawan: 2016). Sementara itu, rekonstruksionisme berupaya mencari kesepakatan antar sesama manusia, agar dapat mengatur tata kehidupan manusia dalam suatu tatanan yang harmonis bagi kemanusiaan dan juga seluruh lingkungannya. Maka, proses dan lembaga pendidikan dalam pandangan rekonstruksionisme perlu merombak tata susunan lama dan membangun tata kelola yang baru. Untuk mencapai tujuan utama tersebut diperlukan kerjasama antara seluruh elemen umat manusia.

Aliran rekonstruksionisme berkeyakinan bahwa tugas penyelamatan dunia merupakan tugas kemanusiaan yang menjadi tanggungjawab semua bangsa dan individu. Karenanya pembinaan kembali daya intelektual dan spiritual yang sehat dapat diwujudkan melalui pendidikan yang tepat atas nilai dan norma yang benar, sehingga terbentuk tatanan dunia baru yang harmonis dalam pengawasan umat manusia (Jalaluddin \& Abdullah Idi: 1997).

Rekonstruksionisme timbul sebagai akibat dari pengamatan tokoh- tokoh pendidikan terhadap masyarakat Amerika khususnya, dan masyarakat Barat umumnya, yang menjelang periode tahun tiga puluhan mengalami goncangan kebudayaan sebagai efek dari Great Depression. Keadaan riil masyarakat modern ternyata tidak selaras dengan harapan ideal modernitas, yakni terwujudnya kebebasan, kesamaan, dan persaudaraan. Untuk mengembalikan kondisi sosial menuju pada keadaan semula yang harmonis, pendidikan diharapkan dapat berperan sebagai instrumen rekonstruksi masyarakat. Artinya, bahwa tujuan pendidikan, kurikulum, metode, peranan guru dan peranan sekolah sebagai lembaga pendidikan hendaklah searah dengan situasi dan kebutuhan masyarakat. Peserta didik dalam sekolah yang bercorak rekonstruksionisme ini diarahkan untuk mampu beradaptasi dan berinteraksi dengan masyarakat di mana ia tinggal. Jadi, orientasi pendidikannya adalah masyarakat.

Imam Bernadib mengartikan rekonstruksionisme sebagai filsafat pendidikan yang menghendaki agar anak didik dapat dibangkitkan kemampuannya untuk secara rekonstruktif menyesuaikan diri dengan tuntutan perubahan dan perkembangan masyarakat sebagai akibat adanya pengaruh dari ilmu pengetahuan dan teknologi (Abd. Rachman Assegaf: 2014). Muhammad Iqbal menuturkan bahwa pendidikan rekonstruksionisme menginginkan pedidikan yang sesuai dengan watak manusia yakni suatu pendidikan yang mengaksentuasikan aktivitasnya pada pemberian pengetahuan kepada subjek didik melalui metode problem solving, suatu cara yang efektif untuk melatih berpikir kreatif, kritis, dan inovatif. Dengan cara ini menurutnya dapat membentuk cakrawala berpikir subjek didik sedemikian rupa sehingga menjadi manusia-manusia yang tanggap terhadap berbagai problematika kehidupannya 


\section{Merekonstruksi Pembelajaran}

dalam masyarakat (Muhmidayeli: 2011).

Sementara itu, Arthur K. Ellis menganggap rekonstruksionisme merupakan perkembangan dari progresivisme dalam pendidikan yang kadang kala diartikan sebagai rekonstruksi sosial. Pengikut aliran rekonstruksionisme, lanjutnya, pada umumnya menganggap bahwa progresivisme hanya memerhatikan problematika masyarakat pada saat itu saja (sedang dihadapi), padahal yang diperlukan di abad kemajuan teknologi yang bergerak demikian cepat ini adalah upaya rekonstruksi masyarakat dan penciptaan tatanan dunia baru secara menyeluruh. Di antara para pendukung aliran ini adalah John Dewey. Secara jelas, kecenderungan Dewey pada rekonstruksionisme dapat diketahui dari pernyataannya:

"The essensial contrast of the idea of education as continuous reconstruction with the other one-sided conception which have been critizied in this and the previous chapter is that is identifies the end (result) and the process ... Every such continous experience or activity is educative, and all education resides in having such experience. It remain only to point out (what will receive more ample attention later) that the reconstruction of experience may be social as well as personel."

Uraian Dewey di atas menerangkan: pertama, rekonstruksionisme menjelaskan akhir (akibat atau hasil) dan proses. Artinya, pendidikan dalam rekonstruksionisme tidak identik dengan ketidakpastian arah atau tujuan dan tanpa melalui proses. Meskipun rekonstruksionisme menganggap bahwa pengalaman itu mengalami perkembangan dan perubahan, tidak berarti pendidikan yang diselenggarakan kehilangan arah dan tujuan. Kedua, pengalaman dan kegiatan secara kontinyu berkembang dan berubah, sejajar dengan tuntutan yang dihadapi oleh pendidikan pada saat itu (di sini rekonstruksionisme berjangkauan lebih jauh dari progresivisme). Ketiga, konstruksi pengalaman itu bisa terjadi baik pada individu maupun kolektif. Konsekuensinya, pendidikan mesti memerhatikan kedua aspek tersebut. Selanjutnya, Dewey menyatakan bahwa pendidikan adalah rekonstruksi atau reorganisasi pengalaman hingga mampu menambah makna pengalaman tersebut, serta dapat meningkatkan kemampuan untuk menentukan arah pada pengalaman berikutnya.

Secara praktis, rekonstruksionisme dalam pendidikan menghendaki tujuan pendidikan adalah peningkatan kesadaran siswa mengenai problematika sosial, politik dan ekonomi yang dihadapi oleh manusia secara global, dan untuk membina dan membekali mereka dengan kemampuan-kemampuan dasar agar bisa menyelesaikan persoalan-persoalan tersebut. Kurikulum dan metode pendidikan menurut rekonstruksionisme haruslah mencakup muatan sosial, politik, dan ekonomi yang sedang dihadapi oleh masyarakat, termasuk juga masalahmasalah pribadi yang dihadapi oleh siswanya. Sementara itu metode dalam kurikulum rekonstruksionis menggunakan disiplin ilmu-ilmu sosial dan metode ilmiah (Muhmidayeli: 


\section{Siti Fatimah}

2011).

Adapun corak aktivitas pembelajaran pada aliran rekonstruksionisme menurut Kinsley Price adalah sebagai berikut,

a. Segala sesuatu yang bercorak otokrasi mesti dihindari, sehingga yang belajar terhindar dari unsur pemaksaan.

b. Guru mesti dapat meyakinkan subjek didiknya akan kemampuannya dalam memecahkan masalah, sehingga masalah yang ada dalam subject matters dapat diatasi.

c. Untuk menumbuhkembangkan keinginan belajar subjek didik, seorang guru mesti mampu mengenali setiap diri subjek didik secara individu.

d. Seorang guru mesti dapat menciptakan kondisi kelas sedemikian rupa sehingga interaksi guru dengan subjek didik dan semua yang hadir dalam satu ruangan kelas dapat berkomunikasi dengan baik, tanpa ada yang menunjukkan sikap otoriter (Muhmidayeli: 2011).

Dari pemaparan di atas dapat disimpulkan bahwa rekonstruksi pendidikan memiliki tujuan khusus yaitu untuk meningkatkan kesadaran siswa mengenai problematika sosial, politik dan ekonomi yang dihadapi oleh manusia secara global, dan untuk membina mereka, membekali mereka dengan kemampuan-kemampuan dasar agar bisa menyelesaikan persoalan- persoalan tersebut.

\section{Pengembangan Rekonstruksionisme dalam Pembelajaran Pendidikan}

\section{Agama Islam}

Semangat kontekstualisasi aliran rekonstruksionisme, yaitu agar pendidikan mampu menjawab persoalan masyarakat, juga terdapat dalam Islam. Dalam ajarannya, Islam memiliki prinsip nilai-nilai muamalah yang dapat diadaptasikan dengan setiap zaman, sehingga diharapkan umat Muhammad SAW mampu menjadi rahmatan lil 'alamin bagi manusia dan rahmat bagi semesta alam.

Seperti dipaparkan di atas, rekonstruksionisme adalah aliran yang berusaha mengubah tatanan lama untuk membangun tatanan yang lebih baru. Dalam kaitannya dengan dunia pendidikan Indonesia, rekonstruksi diperlukan untuk merombak tatanan pendidikan nasional yang memiliki banyak permasalahan, termasuk dalam hal penyelenggaraan pembelajaran pendidikan agama Islam di kelas. Pada konteks ini, rekonstruksionisme diperlukan pada proses pembelajaran Pendidikan Agama Islam (PAI) yang pada dekade ini mengalami perubahan dan perkembangan secara cepat dan signifikan dalam hal teknologi dan pengetahuan.

Rekonstruksi pendidikan agama Islam seharusnya memperhatikan tiga hal. Pertama, peningkatan daya jawabnya terhadap problem kehidupan kontemporer dengan berpegang teguh pada nilai-nilai ajaran al-Quran dan al-Sunnah. Kedua, kepekaan untuk memahamai 
permasalahan yang dihadapi saat ini sehingga pendidikan Islam responsif terhadap kemajuan dengan tetap berpegang teguh pada sumber otentik ajaran Islam. Ketiga, internalisasi nilainilai dan kandungan moral al-Quran dan al-Sunnah kepada anak didik dalam menghadapi kehidupan modern masyarakatnya (Suroto: 2013).

Dari kalangan intelektual muslim, semangat yang senada dengan rekonstruksionisme disuarakan salah satunya oleh filsuf asal Pakistan, Muhammad Iqbal. Reformasi pemikiran keagamaan menurut Iqbal perlu dilakukan dengan cara menanamkan dan membudayakan rasionalitas. Menurutnya, rasionalitas sudah menyatu dengan Islam sejak zaman kenabian. Iqbal yang menguasai ilmu-ilmu logika lantas mengkritisi metode logika ala Yunani kuno yang tidak relevan dengan nilai-nilai keislaman.

Meski mengkritisi logika Yunani, Iqbal sejatinya mendorong budaya rasionalitas dalam ummat Islam. Muhammad Iqbal meyakini bahwa tertutupnya pintu ijtihad yang merupakan ajang pengembangan dari pemikiran Islam yang sebenarnya telah mengakibatkan stagnansi pemikiran di tengah masyarakat Islam. Karena itu, jika pintu ijtihad yang benar dibuka khususnya dalam kasus-kasus yang disepakati oleh umat Islam, akan terbentang jalan bagi umat Islam menuju ke arah kemajuan.

Esensi pendidikan Islam menurut Muhammad Iqbal adalah sebagai pengupayaan perubahan ke arah yang lebih baik, yang mengarah pada pengembangan, menurut tujuantujuan yang telah ditetapkan, meniscayakan pendidikan berorientasi pada masa depan masyarakat, bukan masa sekarang, dan atau hanya sekedar pelestarian nilai-nilai semata. Masyarakat sebenarnya tidak bisa dipandang sebagai sebuah sistem yang kaku. Hal ini dikarnakan didalamnya terdapat jaringan-jaringan yang saling mempengaruhi satu dengan yang lainnya yang bermuara pada sebuah peristiwa yang bergerak kearah perubahanperubahan (Jeeny Rahmayana: 2015).

Dalam konteks pengembangan pembelajaran PAI, rekonstruksi dapat dilaksanakan dalam beberapa aspek pendidikan. Di antaranya pembelajaran tidak hanya menggunakan metode ceramah, tetapi juga menerapkan metode-metode pembelajaran lain yang baru dan menarik. Hal ini telah dilaksanakan di SMA N 4 Yogyakarta untuk menghidupkan miliu belajar. Selain itu, dalam rangka upaya kontekstualisasi zaman, guru PAI dalam menyampaikan pembelajaran perlu mengaitkan materi pembelajaran dengan peristiwa atau kejadian yang terjadi di lingkungan sekitar siswa untuk bisa diambil nilai, hikmah dan juga pembelajaran yang akan menguatkan sensitifitas siswa dalam mengkaji nilai-nilai normatif dari Al Quran dan Hadits. Meskipun Al Quran sebagai rujukan nilai-nilai normatif dan dogmatis, namun para guru perlu menunjukkan urgensinya dengan contoh-contoh yang dihayati para siswa agar siswa dapat memahaminya. Salah satu tantangan guru PAI adalah memahami dan 


\section{Siti Fatimah}

menyampaikan pesan tersirat dari alam yang dihubungkan dengan kandungan nilai yang tersurat dalam Al Quran. Seperti mengambil hikmah dari tragedi jatuhnya pesawat Lion Air JT 610 dengan rute Jakarta-Pangkal Pinang yang jatuh setelah lepas landas dari Bandara Soekarno-Hatta pada Senin tanggal 29 Oktober 2018 pagi. Dari kejadian tersebut guru PAI dapat menghubungkan dengan pembelajaran yaitu tentang materi iman kepada hari akhir. Hari akhir yang dimaksud bukan hanya hari berakhirnya alam semesta beserta isinya saja, namun berakhirnya masa hidup manusia di bumi untuk kembali kepada rabb-Nya yaitu Allah SWT yang tidak diketahui sama sekali kapan waktu terjadinya, di mana seseorang itu meninggal dan dengan cara yang seperti apa malaikat maut mencabut nyawa yang ada pada diri manusia. Seperti firman Allah Swt dalam Qs. Ali Imran ayat 185:

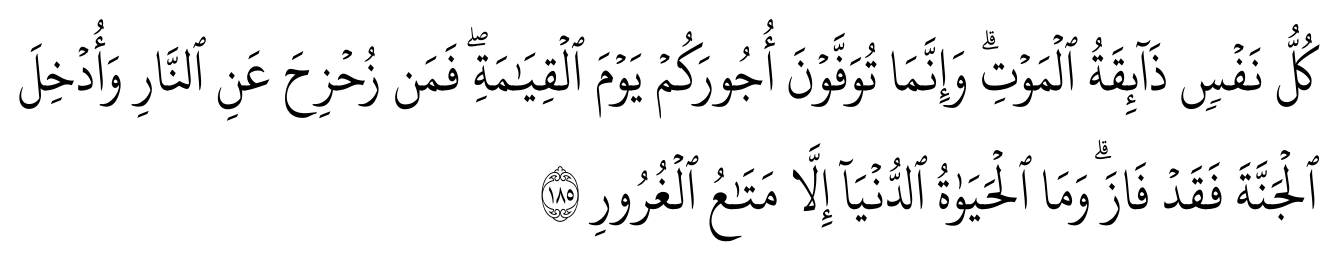

Artinya: Tiap-tiap yang berjiwa akan merasakan mati. Dan sesungguhnya pada hari kiamat sajalah disempurnakan pahalamu. Barangsiapa dijauhkan dari neraka dan dimasukkan ke dalam surga, maka sungguh ia telah beruntung. Kehidupan dunia itu tidak lain hanyalah kesenangan yang memperdayakan. (QS. Ali Imran 185).

Contoh di atas menunjukkan upaya kontekstualisasi pembelajaran pembelajaran PAI, yang merupakan bagian dari filsafat rekonstruksionisme yang menurut Imam Barnadib bertujuan mencetak siswa yang adaptif dengan masalah dan tantangan zamannya.

\section{Upaya Guru PAI dalam Mengimplementasikan} Rekonstruksionisme dalam Pembelajaran PAI dan Budi Pekerti pada Siswa di SMA N 4 Yogyakarta.

Untuk bisa menciptakan pendidikan yang rekonstruktif tentu saja harus ada upaya dari guru Pendidikan Agama Islam dalam menanggapi problem yang ada di sekeliling siswa, sehingga siswa dapat mencapai dari tujuan pendidikan. Adapun pandangan aliran rekonstruksionisme terhadap belajar juga dapat dilihat dari poin-poin berikut:

1) Tujuan pendidikan 
Pada aliran rekonstruksionisme tujuan pendidikan adalah sebagai berikut,

a. Sekolah-sekolah rekonstruksionis berfungsi sebagai lembaga utama untuk melakukan perubahan sosial, ekonomi, dan politik masyarakat.

b. Tugas sekolah-sekolah rekonstruksionis adalah mengembangkan "insinyurinsinyur" sosial serta warga-warga negara yang mempunyai tujuan mengubah secara radikal wajah masyarakat masa kini.

c. Tujuan pendidikan rekonstruksionis adalah membangkitkan kesadaran para peserta didik tentang masalah sosial, ekonomi dan politik yang dihadapi umat manusia dalam skala global, dan mengajarkan kepada mereka ketrampilan ketrampilan yang diperlukan untuk mengatasi masalah tersebut (Abdul Haris: 2014).

Dari tujuan di atas jika dikontekstualisasikan dalam pembelajaran PAI maka tujuan PAI haruslah sesuai dengan konsep rekonstruksionis yaitu harus sensitif dalam melihat kesenjangan atau masalah yang sedang dihadapi untuk bisa menyesuaikan dengan tujuan pembelajaran yang akan dicapai. Tujuan pembelajaran PAI adalah untuk menghasilkan manusia terbaik atau insan kamil dengan hidup tenang dan produktif.

Upaya guru Pendidikan Agama Islam harus paham dengan tujuan yang harus dicapai oleh siswa didik. Di SMA Negeri 4 Yogyakarta dalam mewujudkan salah satu visi dari sekolah yaitu unggul dalam Imtaq (Iman dan Taqwa) dapat diwujudkan dengan kegiatan-kegiatan pokok dan kegiatan penunjang seperti pembelajaran PAI dan Budi Pekerti yang dilaksanakan setiap pekannya tiga jam pelajaran sesuai dengan peraturan pemerintah. Selain itu, kegiatan penunjang yang dilaksanakan di SMA N 4 Yogyakarta antara lain adalah tadarus al-Quran setiap dua hari sekali sebelum pembelajaran dimulai bagi siswa muslim di kelas, sedangkan siswa non-muslim mendapatkan siraman rohani di ruang agama. Kegiatan penunjang lainnya seperti kegiatan shalat Dzuhur berjamaah di sekolah, kegiatan mentoring (forum kecil untuk mengkaji Islam) di luar pembelajaran di kelas. Aktivitas-aktivitas tersebut merupakan upaya guru dan sekolah untuk menciptakan siswa-siswi yang beriman dan bertakwa di sekolah negeri dengan populasi yang lebih heterogen.

2) Peserta didik

Siswa hendaknya dipandang sebagai bunga yang sedang mekar, yang mengandung arti bahwa siswa adalah generasi muda yang sedang tumbuh menjadi manusia pembangunan masyarakat masa depan. Anak yang sedang tumbuh harus mendapatkan bimbingan berdasarkan petunjuk yang benar yaitu sesuai dengan al-Quran dan al-Hadits, untuk bisa mempersiapkan diri menjadi seorang pemimpin untuk membangun masyarakat yang madani.

Sepatutnya siswa mengembangkan keilmuannya bukan hanya sebagai ilmu teoritis saja, namun harus dikembangkan dengan praktik secara terpantau. Sebagai contoh, siswa 


\section{Siti Fatimah}

mendapatkan teori tentangakhlakterpuji kepada guru, maka siswa harus mengimplementasikan teori akhlak yang disampaikan di kelas kepada guru secara nyata dalam kehidupan seharihari. Selain itu, peserta didik patutnya memanfaatkan teknologi yang saat ini berkembang untuk mengembangkan tatanan pendidikan yang lebih rekonstruktif. Dalam kaitannya dengan agama, agama bukanlah penghalang peserta didik untuk mengikuti perkembangan teknologi dunia, namun justru menjadi salah satu rujukan perkembangan ilmu sains dan teknologi. AlQur'an sendiri mengandung banyak fakta-fakta yang sesuai dengan penemuan sains, seperti kandungan madu yang telah disebutkan dalam Qs. Al-Nahl ayat 69:

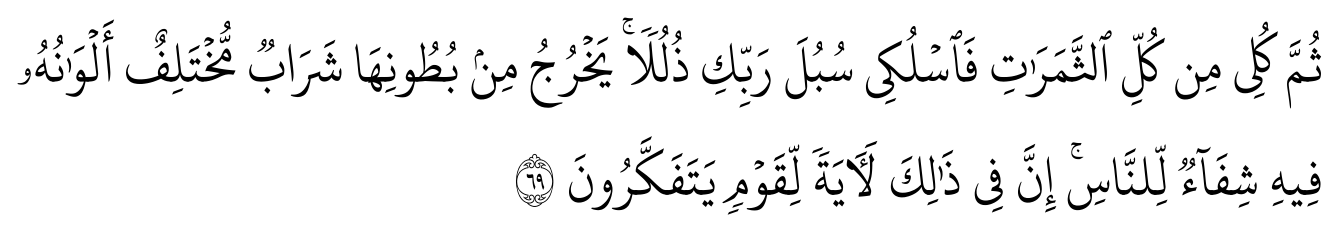

Artinya: Kemudian makanlah dari tiap-tiap (macam) buah-buahan dan tempuhlah jalan Tuhanmu yang telah dimudahkan (bagimu). Dari perut lebah itu ke luar minuman (madu) yang bermacam-macam warnanya, di dalamnya terdapat obat yang menyembuhkan bagi manusia. Sesungguhnya pada yang demikian itu benar-benar terdapat tanda (kebesaran Tuhan) bagi orang-orang yang memikirkan. (QS. Al-Nahl 69).

Hal-ihwal inilah yang seharusnya menjadi penyemangat para peserta didik untuk mengkaji al-Quran agar mendapatkan ilmu yang lebih rekonstruktif lagi. Suatu pembelajaran akan lebih melekat di dalam ingatan siswa apabila dikaitkan dengan alam sekitar siswa. Pengetahuan yang melekat dan dihayati siswa pada akhirnya akan menjadikan para siswa semakin dekat dan bersyukur kepada Tuhan semesta alam.

3) Pendidik

Pada aliran rekonstruksionisme, pendidik memiliki posisi yang penting karena harus membuat peserta didik mampu memahami masalah-masalah yang ada di lingkungan mereka. Pendidik harus membantu peserta didik mengenali masalah-masalah tersebut sehingga mereka terdorong untuk memecahkannya. Sebagai contoh, ketika di lingkungan peserta didik ditemukan permasalahan tawuran antar pelajar, pendidik harus memberikan pengarahan dari sisi syariat Islam dalam pembelajaran di kelas. Pendidik harus menjelaskan bahwa Islam mengatur umat manusia untuk bisa saling memaafkan, saling melindungi dan menghormati orang lain. Allah Swt adalah tuhan yang maha pemaaf, sehingga sebagai hamba Allah pun juga harus menjadi orang yang pemaaf. Dengan penanaman nilai maaf tersebut, diharapkan para siswa terdorong untuk memaafkan dan tidak mudah terpancing untuk menumpahkan 


\section{Merekonstruksi Pembelajaran}

emosi dalam tindak tawuran.

Contoh yang kedua adalah tentang pemanfaatan media sosial. Sebagai umat agama Islam yang sangat mengagungkan ilmu pengetahuan, kaum muslimin tidak boleh antipati terhadap perkembangan budaya dan teknologi. Oleh karena itu, pendidik harus mengajarkan kepada siswa untuk melek dan adaptif dengan perkembangan pengetahuan dan teknologi. Ini selaras dengan nilai rekonstruksionisme yang mendorong siswa untuk memiliki kemampuan problem solving terhadap permasalahan masyarakat. Mengingat kondisi zaman saat ini banyak bersentuhan dengan dunia teknologi, maka para siswa perlu dibekali pengetahuan dan keterampilan teknologis agar dapat memecahkan permasalahan yang dihadapi masyarakat di masa kini dan masa depan. Namun, selain pengajaran pengetahuan dan keterampilan teknologi, siswa perlu juga diberikan pendampingan spiritual, agar pemanfaatan terhadap perkembangan teknologi membawa dampak positif dan kebermanfaatan.

\section{4) Kurikulum}

Aliran rekonstruksionisme mengisi kurikulum dengan tema pembelajaran yang berorientasi pada kebutuhan-kebutuhan siswa pada masa yang sedang dihadapi dan masa yang akan datang. Untuk itu, kurikulum PAI harus diisi dengan banyak permasalahan ibadah, muamalah, fikih dan perkembangannya, termasuk di dalamnya pembahasan tentang masalahmasalah pribadi (ahwal syakhsiyah) dan program-program perbaikan yang ditentukan secara ilmiah untuk aksi kolektif. Sehingga kurikulum menjadi salah satu aspek yang penting di dalam mengembangkan materi yang rekonstruktif yang disesuaikan dengan perkembangan sosial dan zaman.

SMA N 4 Yogyakarta sebagai sekolah negeri tentunya harus menyesuaikan kurikulum dengan peraturan pemerintah yang sudah ditetapkan. Lantas bagaimana kurikulum dapat dikembangkan agar selaras dengan semangat rekonstruksionisme? Masalah ini dapat dipecahkan dengan pelaksanaan pembelajaran di mana guru PAI mendapatkan keleluasaan untuk mengembangkan kurikulum tersebut dengan kondisi yang terjadi di sekolah. Contohnya, untuk melihat adab seorang siswa tentu saja upaya guru untuk menilai dengan mengamati kebiasaan para siswa saat pembelajaran berlangsung atau diluar kelas, adab siswa terhadap guru lainnya, maupun adab siswa terhadap siswa lainya.

5) Metode pembelajaran

Metode pembelajaran merupakan aspek penting dalam rekonstruksionisme. Pembelajaran akan lebih efektif jika pendidik menggunakan metode pembelajaran yang melibatkan peserta didik untuk aktif dalam proses pembelajaran. Demikian menggunakan metode pemecahan masalah (problem solving), analisis kebutuhan, dan penyusunan program untuk perbaikan pembelajaran di kelas menjadi suatu hal yang wajib diupayakan oleh 


\section{Siti Fatimah}

pendidik dalam kegiatan belajar mengajar.

Pada pembelajaran PAI, variasi metode pembelajaran merupakan hal yang mutlak, karena ilmu yang terkandung dalam pelajaran PAI tidak cukup disampaikan melalui metode ceramah saja. Pendidik perlu menciptakan variasia metode pembelajaran sesuai dengan tema pembelajaran. Sebagai contoh pembelajaran jinayah, agar siswa dapat memahami persoalan atau masalah yang berkaitan dengan materi dan menumbuhkan sikap aktif dan berpikir kritis siswa. Maka guru menggunakan metode pembelajaran aktif dengan strategi "every one is a teacher here"(Hamrani: 2014) yaitu sebuah strategi guna memperoleh partisipasi kelas yang besar dan bertanggungjawab individu. Strategi ini memberikan kesempatan pada setiap peserta didik untuk bertindak sebagai “pengajar” terhadap peserta didik lain.

Upaya lain dalam mengoptimalkan pembelajaran yang rekonstruktif adalah dengan memanfaatkan media sosial dalam belajar. Di SMA N 4 Yogyakarta, guru memanfaatkan media sosial seperti Instagram untuk menjadi salah satu media pembelajaran yaitu dengan meminta siswa membuat quotes (kutipan) yang berisi ajakan untuk berperilaku baik serta menjauhi perbuatan dosa. Hal itu bertujuan agar siswa mampu memahami materi yang dipelajari serta mampu belajar menyampaikan pesan nasehat yang bermanfaat untuk orang lain. Selain itu, guru SMAN 4 Yogyakarta juga mengadakan social worker, yaitu kegiatan sosial yang dilaksanakan di lingkungan sekitar tempat tinggal siswa dengan tujuan membaurkan para siswa dengan masyarakat sekeliling. Aktivitas yang dilaksanakan bermacam-macam, seperti menjadi panitia Ramadhan, mengikuti kegiatan gotong-royong, bakti sosial, dan lain sebagainya. Kegiatan-kegiatan ini diharapkan menjadikan siswa mampu menangkap permasalahan riil dalam dinamika masyarakat dan lingkunganya serta dapat memberikan solusi lewat keterlibatan langsung.

\section{Penutup}

Pendidikan dalam rekonstruksionisme menghendaki agar anak didik mampu menyesuaikan diri dengan tuntutan perubahan dan perkembangan masyarakat sebagai akibat adanya pengaruh dari ilmu pengetahuan dan teknologi. Asumsi dasar dalam rekonstruksionisme adalah hipotesis bahwa masyarakat dunia sedang dalam kondisi kritis multidimensi. Oleh karena itu, diperlukan upaya-upaya perbaikan (rekonstruksi) tatanan masyarakat agar peradaban manusia tidak mengalami kehancuran. Rekonstruksionisme memandang pendidikan sebagai bagian penting dari upaya rekonstruksi tersebut. Untuk mewujudkan tujuan tersebut, pendidikan formal dapat menjadi agen utama dalam rekonstruksi tatanan sosial dengan memberlakukan metode-metode pengajaran yang didasarkan pada prinsip-prinsip demokratis. 
Pada masa ini, pendidikan harus menyesuaikan diri dengan ilmu pengetahuan dan teknologi yang berkembang pesat. Oleh karena itu, rekonstruksi dilakukan dengan penguasaan ilmu pengetahuan dan keterampilan teknologi kontemporer. Dalam konteks pembelajaran PAI, untuk mengembangakan pendidikan yang ramah dengan zaman adalah dengan mengupayakan adaptasi pembelajaran PAI dengan media-media pembelajaran yang memanfaatkan teknologi terbaru, contohnya media sosial. Selain itu, pengajaran PAI juga harus dapat diintegrasikan dengan pengajaran keterampilan memecahkan masalah, berfikir kritis dan keterlibatan secara langsung dengan permasalahan sosial kemasyarakatan dan lingkungan. Hal-ihwal yang mencirikan pendidikan rekonstruksionis tersebut telah diterapkan secara sistematis di SMA N 4 Yogyakarta. 


\section{Siti Fatimah}

\section{Daftar Pustaka}

Assegaf, Abd. Rachman. (2014). Filsafat Pendidikan Islam, Jakarta: Raja Grafindo Persada.

Haris, Abdul. (2014). Aliran Rekonstruksionisme dalam Pandangan Filsafat Pendidikan Islam, makalah dipresentasikan dalam Program Pasca Sarjana, STAIN Pekalongan.

Hamruni. (2014). Pembelajaran Berbasis Edutainment, Yogyakarta: Investidaya.

Jalaluddin dan Idi, Abdullah. (1997). Filsafat Pendidikan: Manusia, Filsafat dan Pendidikan, Jakarta: Gaya Media Pratama.

Knight, George R. (2007). Filsafat Pendidikan, penerjemah: Mahmud Arif, Yogyakarta: Gama Media.

Kristiawan, Muhammad. (2016) Filsafat Pendidikan: The Choice is Yours, Yogyakarta: Valia Pustaka.

Muhmidayeli. (2011). Filsafat Pendidikan, Bandung: Refika Aditama.

Noor, Wahyudin. (2014). Rekonstruksi Pendidikan Agama Islam. Jurnal Qathruna, Vol. 1 No. 1, 40-59.

Rahmayana, Jeeny. (2015). Filsafat Rekonstruksionisme dalam Pendidikan Islam Studi atas Pemikiran Muhammad Iqbal. Jurnal Tamaddun Ummah, Vol. 1, No. 1, 1-13.

Suroto. (2013). Rekonstruksi Pendidikan Islam sebagai Paradigma Alternatif Pendidikan di Indonesia. Al-Mabsut, Vol. 6, No. 1, 1-14. 